\title{
Sistem Penunjang Keputusan Relevansi Kegiatan Praktek Kerja Lapangan dengan Menggunakan Metode SAW
}

\author{
M. Taufiq ${ }^{1}$, Arif Hadi Sumitro ${ }^{2}$ \\ 1,2 Manajemen Informatika/Sekolah Tinggi Ilmu Komputer PGRI Banyuwangi \\ Jl. Jenderal Ahmad Yani No.80, Taman Baru, Banyuwangi, Indonesia \\ e-mail: ${ }^{1}$ mtaufiq39@gmail.com, ${ }^{2}$ radenarifhadisumitro@gmail.com
}

\begin{tabular}{llll}
\hline Informasi Artikel Diterima: 25-09-2020 Direvisi: 23-02-2021 & Disetujui: 01-03-2021 \\
\hline
\end{tabular}

\begin{abstract}
Abstrak
Setiap kegiatan praktek kerja industry memiliki penilaian yang tidak semuanya sesuai dengan realita. Salah satu penilaian yang bisa dilakukan oleh pihak sekolah terkait kegiatan praktik mandiri dilapangan terhadap perusahaan tidak semuanya bisa dilakukan sesuai dengan harapan. Namun demikian, usaha untuk terus memberikan kualitas praktek kerja industry PKL harus dilakukan dengan memaksimalkan minimal kesalahan dalam menentukan tempat PKL. Banyaknya siswa yang harus ditempatkan pada perusahaan untuk melaksanakan praktek kerja industry mengakibatkan sulitnya menentukan perusahaan yang memiliki relevansi tinggi terhadap kegiatan dan juga jurusan praktek siswa. Alhasil ada sebagian dari siswa yang memiliki kompetensi baik namun ditempatkan pada perusahaan yang sama sekali kurang relevan sesuai dengan standar kegiatan PKL. Untuk itu perlu dilakukan monitoring dalam mengevaluasi relevansi pada perusahaan yang digunakan untuk penempatan praktek kerja industry dengan mengambil objek kelayakan kriteria pada perusahaan terpilih dengan menggunakan metode Simple Additive Weighting, sehingga kedepannya diharapkan.
\end{abstract}

Kata Kunci: SAW, PKL, Relevansi

\begin{abstract}
Every industrial work practice activity has an assessment that is not all in accordance with reality. One of the assessments that can be carried out by the school regarding independent practice activities in the field of companies is not everything can be carried out as expected. However, efforts to continue to provide quality PKL industry work practices must be done by maximizing a minimum of errors in determining where street vendors are. The large number of students who must be placed in companies to carry out industrial work practices makes it difficult to determine companies that have high relevance to activities and student practical majors. As a result, there are some students who have good competence but are placed in companies that are not at all relevant according to the standard of street vendors. For this reason, monitoring is necessary in evaluating the relevance of the company used for the placement of industrial work practices by taking the object of the eligibility criteria for the selected company using the Simple Additive Weighting method, so that in the future it is expected
\end{abstract}

Keywords: SAW, Field Practice, Relevance

\section{Pendahuluan}

Dalam melancarkan kegiatan belajar pada sekolah kejuruan menengah SMK, akan ada kesempatan bagi siswa untuk melakukan praktek kerja industri atau praktek kerja lapangan PKL. Kegiatan rutin yang dilakukan setiap tahun oleh pihak sekolah akan melibatkan siswa serta stakeholder atau DU/DI dalam pelaksanaan praktek kerja tersebut.

Agenda yang dilakukan dalam pelaksaanaan PKL tersebut melibatkan banyak kegiatan termasuk kegiatan dalam penempatan siswa praktek kerja itu sendiri. Penelitian ini melanjutkan dari penelitian sebelumnya yaitu yang membahas tentang sistem praktek kerja lapangan dengan menggunakan metode RAD serta pengujian SUS(Sumitro \& Taufiq, 2019).

Pada penelitian sebelumnya membahas tentang sistem yang digunakan untuk membantu melakukan monitoring terhadap berlangsungnya kegiatan praktek kerja industri. Namun melihat pemasalahan dilapangan, ditemukan hal yang cukup penting dalam berjalannya kegiatan sistem praktek kerja lapangan. Adapun 
permasalahan yang cukup di signifikan dalam proses kegiatan PKL tersebut adalah tentang seperti apa stake holder atau perusahaan yang bisa membantu mahasiswa PKL untuk bisa melaksanakan PKL sesuai dengan jurusan atau setidaknya relevan terhadap jurusan sekolah yang sedang dijalani.

Permasalahan tersebut adalah permasalahan umum yang dihadapi oleh sekolah ketika mengirimkan siswanya untuk melaksanakan PKL. Pelaksanaan PKL dilokasi yang dituju, siswa akan mendapatkan kegiatan yang bervariasi sesuai dengan kebutuhan yang ada di lokasi praktek, hal ini yang menyebabkan tujuan siswa dalam melaksanakan praktek tidak tercapai.

Agar tujuan kegiatan PKL dapat tercapai harus ditunjang dengan kesesuaian kegiatan yang dilakukan di lokasi kegiatan. Dengan berbekal data kegiatan yang sudah dilakukan oleh siswa pada kegiatan yang lalu.

Dari data yang ada kemudian data diolah dengan menggunakan metode Simple Additive Weighting(SAW) sehingga akan didapatkan urutan lokasi yang sesuai dengan jurusan siswa yang sedang melakukan PKL.

Sehingga dalam penelitian ini akan dibuatkan sebuah sistem penunjang keputusan yang membantu pihak sekolah dalam menentukan lokasi yang akan ditempati oleh siswa. Dengan demikian tugas dari sekolah dapat lebih mudah dan tujuan dari kegiatan PKL siswa dapat terpenuhi.

Dari uraian tersebut dipandang perlu untuk dibuatkan system pendukung keputusan dalam mengukur relevansi kegiatan siswa praktek kerja lapangan dengan mengimplementasikan Simple Additive Weighting (SAW) sebagai metode pengambilan keputusanya.

\section{Studi Literatur}

System pendukung keputusan adalah salah satu bidang dalam pembuatan system informasi. Pembuatan system pendukung keputusan ditujukan sebagai alat yang membantu dalam pembuatan keputusan yang dibuat oleh orang yang punya wewenang dalam pembuatan keputusan.

Dalam pembuatanya seorang programmer akan menggunakan berbagai alat untuk dapat mencapainya. Sebagai dasar dalam pembuatan sebuah system pendukung keputusan yang dibutuhkan adalah metode yang tepat untuk melandasinya. Dikarenakan SPK yang dibuat memiliki banyak kriteria, maka akan digunakan metode yang tergolong dalam MCDM (Multi Criteria Decision Making) dimana untuk membuat keputusan yang banyak kriteria yang digunakan akan lebih mudah bila kita menggunakan metode yang tepa(Norman et al., 2020),(Winarso et al., 2018),(Taufiq et al., 2017). Diantara metode yang tergolong dalam MCDM adalah simple additive weighting (SAW) dimana dalam tahapan prosesnya menggunakan banyak kriteria sebagai pijakan dalam pembuatan keputusan(Ginting, 2020).

Metode SAW adalah metode yang menggunakan banyak kriteria dalam proses pengerjaanya. Sehingga dalam banyak kasus penggunaan metode SAW cocok dan mendapatkan hasil akhir yang diharapkan penggunanya(Endang, n.d.).

Metode SAW juga terkenal dengan metode penjumlahan pada kriteria terbobot(Sugiyono, 2012). Konsep dasar penggunaan metode SAW adalah bagaimana mencari penjumlahan terbobot dari rating yang diberikan pada tiap alternatif dari semua atribut yang ada(Mujiastuti et al., 2017).

Persamaan yang digunakan dalam metode ini adalah :

$$
\begin{aligned}
\mathrm{R}_{\mathrm{ij}} & =\frac{X_{i j}}{\operatorname{Max} X_{i j}} \\
\mathrm{R}_{\mathrm{ij}} & =\frac{\min X_{i j}}{X_{i j}}
\end{aligned}
$$

Dimana :

$\mathrm{R}_{\mathrm{ij}}=$ Rating nilai ternormalisasi

$\operatorname{Max} X_{i j}=$ Nilai Maksimal setiap kriteria

Min $X_{i j}=$ Nilai minimal setiap kriteria

$\mathrm{X}_{\mathrm{ij}}=$ Atribut yang dimiliki tiap kriteria

Persamaan 1 digunakan saat $\mathrm{j}$ berada pada benefit, sedangkan persamaan 2 digunakan saat $\mathrm{j}$ berada pada posisi cost(Arianto et al., 2020).

Untuk menghitung bobot setiap kriteria dapat menggunakan persamaan:

$$
\mathrm{W}=\frac{c_{1}}{c_{1}+\cdots+c_{N}} X 100 \%
$$

Sedangkan untuk menghitung preferensi setiap kriteria didapatkan dengan persamaan berikut:

$$
V_{i}=\sum_{j=1}^{n} W_{j} R_{i j}
$$

Penggunaan metode SAW adalah dengan melalui 4 langkah berikut:

1. Tentukan kriteria yang mempengaruhi.

2. Menentukan rating kecocokan setiap alternatif dengan seluruh alternatif yang ada.

3. Membuat matrik kemudian dinormalisasi.

4. Lakukan perangkingan dengan cara 
System pendukung keputusan yang akan dibuat adalah system pendukung keputusan berbasis web yang dibangun dengan menggunakan bingkai kerja Codelgniter yang berbasis bahasa pemrograman PHP.

Codeigniter adalah sebuah bingkai kerja berbasis PHP yang sifatnya basis kode sumber terbuka yang dikembangkan oleh Ellis Lab, bingkai kerja ini pertama kali diluncurkan pada 28 pebruari 2006 untuk versi terbaru saat ini codeigniter sudah mencapai versi 4.0.4 yang sudah modern menggunakan composer untuk downloadnya. Karena bersifat basis kode terbuka codeigniter bebas digunakan oleh siapa saja tanpa harus membayar lisensi untuk menggunakanya. Pengunaan bingkai kerja bertujuan untuk mempercepat pengerjaan sebuah project dengan mengabaikan beberapa fungsi yang sudah disiapkan oleh bingkai kerja sehingga kita tidak harus membuatnya sendiri(Sugihartono, 2018).

Banyak plugin yang sudah disiapkan oleh codeigniter yang bisa kita gunakan yang akhirnya akan membuat kita lebih cepat dalam menyelesaikan project yang dibuat.

Codeigniter berbasis PHP dimana bahasa pemrograman PHP sendiri adalah basis kode terbuka sama halnya dengan codeigniter, maka penggunaan bahasa pemrograman PHP juga bebas digunakan(Susanto et al., 2016).

Dengan demikian pembuatan system informasi menggunakan bahasa pemrograman PHP tidak membutuhkan pembayaran lisensi kepihak manapun, akan tetapi hasil pembuatan system dengan bahasa pemrograman ini dijual dengan harga yang pantas sebagai apresiasi pengguna untuk pekerjaan programmer.

Sedangkan untuk pembuatan database digunakan MySQL sebagai media penyimpanan datanya. Penggunaan MySQL sebagai media penyimpanan didasarkan pada gratisnya MySQL untuk dapat digunakan.

MySQL sendiri adalah suatu DBMS (database management system) dimana perintah dasarnya menggunakan Structured Query Langguage (SQL). MySQL bersifat RDBMS (Relational Database Management sistem) yang didalamnya terdiri dari table yang berisi kolom dan baris(Bambang Sumantri \& Mahardika, 2020). Hampir setiap kolom dan baris pada database MySQL akan memiliki relasi pada kolom dan baris lain pada table yang berbeda.

MySQL merupakan platform database yang diluncurkan pada tahun 1995 yang dihasilkan dari kerja sama antara UNIREG, mSQL dan TcX. Sedangkan sekarang MySQL dikembangkan dibawah perusahaan Oracle.

\section{Metode Penelitian}

\section{Tahapan Penelitian}

Tahapan yang dilalui dalam penelitian ini adalah pertama Analisa kebutuhan system yang akan dibuat dengan melakukan studi literatur dan melakukan wawancara kepada stake holder yang menjadi pelaksana kegiatan PKL. Dalam penelitian ini peneliti bekerja sama dengan stake holder dari SMK PGRI 1 Giri.

Langkah kedua setelah Analisa kebutuhan, dilakukan pengumpulan data yang dilakukan dengan bekerja sama dengan para stake holder yang diwawancarai.

Langkah ketiga melakukan perancangan system. Dimana peneliti membuat rancangan system yang akan dibuat berupa prototype aplikasi.

Langkah keempat implementasi rancangan yang dibuat kedalam aplikasi. Dari rancangan yang sudah dibuat peneliti mengimplementasikan dalam Bahasa pemrograman yang sudah ditentukan. Pada tahapan ini peneliti bekerjasama dengan programmer untuk membuat system informasi yang dibuat.

Langkah terakhir adalah melakukan uj coba terhadap system yang dibuat. Ujicoba melibatkan peneliti dan stake holder yang ada di SMK PGRI 1 Giri.

Adapun tahapan yang dilalui oleh peneliti dapat dilihat seperti gambar berikut:

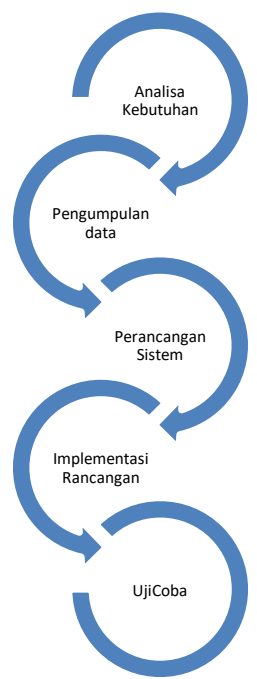

Gambar 1. Tahapan Penelitian

\section{Rancangan Sistem}

Pada perancangan sistem yang dibuat, mengoptimalkan setelah pendataan siswa prakerin, maka akan dipilah dulu perusahaan atau DU/DI mana saja yang akan dipilih untuk didistribusikan para siswa PKL. Pada tahapan ini jika siswa yang memiliki ketrampilan lebih, akan didistribusikan pada perusahaan yang mempunyai peringkat tertinggi, sehingga nantinya ketrampilan yang didapat bisa diimplementasikan dengan maksimal. 


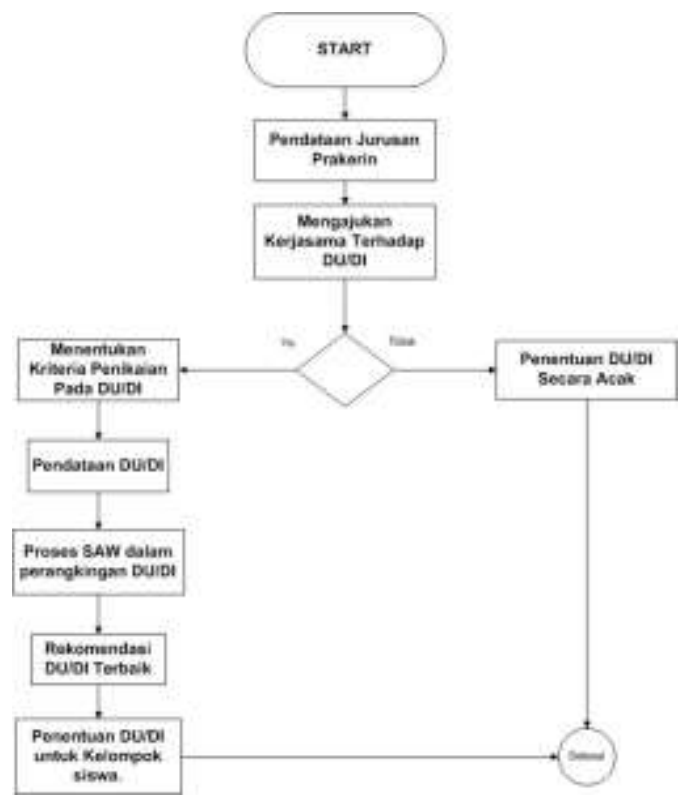

Gambar 2. Alur System

3. Analisa Kebutuhan Input System

Input yang diinginkan pada system ini mengharuskan kita untuk mengatur kriteria mana yang dibutuhkan oleh system hal ini berhubungan dengan penggunaan metode SAW yang peneliti gunakan. Input system juga mengacu pada objek apa saja yang berpengaruh dalam penggunaan system (Hafiz et al., 2020).

Pada metode SAW Langkah pertama yang dilakukan adalah menentukan kriteria yang telah ditentukan oleh sekolah sehingga sesuai dengan prosedur yang diinginkan sekolah.

\section{Penentuan Kriteria}

Kriteria yang berpengaruh dalam kasus yang dibahas oleh peneliti meliputi :

Table 1. Kriteria yang Berpengaruh

\begin{tabular}{cl}
\hline KRITERIA & \multicolumn{1}{c}{ KETERANGAN } \\
\hline C1 & Simulasi dan Komunikasi Digital \\
C2 & Sistem Komputer \\
C3 & Komputer dan Jaringan \\
C4 & Dasar Desain Grafis \\
C5 & Pemrograman Dasar \\
C6 & Teknologi jaringan berbasis Luas \\
C7 & Administrasi Infrastruktur Jaringan \\
\hline
\end{tabular}

5. Penentuan Bobot (Urgensi Dan Preferensi)

Setelah kriteria yang berpengaruh sudah di inventarisir, maka Langkah berikutnya adalah menentukan bobot yang digunakan. Bobot yang digunakan dengan menggunakan skala 1-5 dimana semakin tinggi bobot yang diberikan maka akan semakin baik (Khairullah \& Mahdiana, 2019).
Tabel 2. Bobot Urgensi dan preferensi

\begin{tabular}{ll}
\hline BOBOT & \multicolumn{1}{c}{ KETERANGAN } \\
\hline $\mathbf{1}$ & Sangat Buruk (SBU) \\
$\mathbf{2}$ & Kurang Baik (KB) \\
$\mathbf{3}$ & Cukup Baik (CB) \\
$\mathbf{4}$ & Baik (B) \\
$\mathbf{5}$ & Sangat Baik (SBA) \\
\hline
\end{tabular}

6. Penentuan Bobot Preferensi Tiap Kriteria

Penentuan bobot preferensi tiap kriteria diurutkan berdasarkan urgensinya dalam mempengaruhi masalah yang dihadapi.

Pemberian bobot dilakukan pada tiap kriteria dengan memperhatikan pengaruhnya terhadap masalah yang dihadapi.

Tabel 3. Bobot Referensi Simulasi dan Komunikasi Digital

\begin{tabular}{lc}
\hline \multicolumn{1}{c}{ Rating Urgensi } & Bobot \\
\hline Menggunakan kata yang tidak & 1 \\
santun dan penggunaan kata yang & \\
salah dalam berkomunikasi & \\
sehingga tidak sesuai dengan & \\
tingkatan dan tujjuan & \\
Menggunakan kata yang kurang & 2 \\
santun dan penggunaan kata yang & \\
salah namun masih dalam tahap & \\
wajar sehingga yang diajak \\
berkomunikasi masih bisa \\
mengerti. \\
Menggunakan kata santun dan \\
pemilihan kata yang tepat sesuai \\
dengan tingkatan dan kepentingan \\
namun dengan dilengkapi dengan \\
symbol yang kurang pantas \\
Menggunakan kata santun dan \\
pemilihan kata yang tepat sesuai \\
dengan tingkatan dan kepentingan \\
namun dengan dilengkapi dengan \\
symbol \\
Menggunakan kata santun dan \\
pemilihan kata yang tepat sesuai \\
tingkatan dan kepentingan tanpa \\
menggunakan symbol.
\end{tabular}

Tabel 4. Bobot Referensi Sistem Komputer

\begin{tabular}{lc}
\hline \multicolumn{1}{c}{ Rating Urgensi } & Bobot \\
\hline Tidak dapat membedakan & 1 \\
operating system pada computer & \\
sehingga tidak dapat melakukan & \\
troublesot terhadap masalah pada & \\
perangkat. & \\
Tidak dapat membedakan & 2 \\
operating system pada computer & \\
namun dapat melakukan troublesot & \\
masalah pada perangkat & \\
$\begin{array}{l}\text { Dapat membedakan operating } \\
\text { system pada computer namun tidak } \\
\text { dapat melakukan troublesot }\end{array}$ & 3 \\
\end{tabular}


Mampu membedakan operating

4

system pada computer dan

mampu melakukan troublesot pada

masalah tertentu pada perangkat

Mampu membedakan operating

5

system oada computer dan

mampu melakukan troublesot pada

semua masalah yang terjadi pada

perangkat

Tabel 5. Bobot Referensi Komputer dan jaringan

\begin{tabular}{lc}
\multicolumn{1}{c}{ Rating Urgensi } & Bobot \\
\hline Memahami namun belum mampu & 1 \\
mengimplementasikan tata cara & \\
merakit dan install os beserta & \\
software yang dibutuhkan, tidak & \\
memahami dan tidak mampu & \\
membangun jaringan sederhana & 2 \\
Memahami dan mampu & \\
mengimplementasikan tata cara & \\
merakit dan install os beserta & \\
software yang dibutuhkan, tidak & \\
memahami dan tidak mampu & \\
membangun jaringan sederhana & \\
Memahami dan mampu & 3 \\
mengimplementasikan tata cara & \\
merakit dan install os beserta & \\
software dibutuhkan, & \\
memahami namun belum mampu & \\
membangun jaringan sederhana & \\
Memahami dan mampu & \\
mengimplementasikan tata cara & \\
merakit dan install os beserta & \\
software yang dibutuhkan, \\
memahami namun belum mampu \\
membangun jaringan sederhana \\
dengan sempurna \\
Memahami dan mampu \\
mengimplementasikan tata cara \\
merakit dan install os beserta \\
software yang dibutuhkan, \\
memahami dan mampu \\
membangun jaringan sederhana \\
\end{tabular}

Tabel 6. Bobot Referensi Dasar Desain Grafis

\begin{tabular}{lc}
\hline \multicolumn{1}{c}{ Rating Urgensi } & Bobot \\
\hline $\begin{array}{l}\text { Tidak mampu membuat desain } \\
\text { dengan tools (Photoshop dan Corel }\end{array}$ & 1 \\
$\begin{array}{l}\text { Draw) } \\
\text { Hanya mampu membuat desain } \\
\text { dengan arahan dari pembimbing }\end{array}$ & 2 \\
$\begin{array}{l}\text { Hanya mampu membuat desain } \\
\text { sederhana dengan tools Photoshop }\end{array}$ & 3 \\
$\begin{array}{l}\text { dan Corel Draw } \\
\text { Hanya mampu membuat desain }\end{array}$ & 4 \\
$\begin{array}{l}\text { unik dengan salah satu tools } \\
\text { (Photoshop dan Corel Draw) }\end{array}$ & \\
$\begin{array}{l}\text { Mampu membuat desain yang unik } \\
\text { dengan tools Photoshop dan Corel } \\
\text { Draw }\end{array}$ & 5 \\
\hline
\end{tabular}

Tabel 7. Bobot Referensi Pemrograman Dasar

\begin{tabular}{lc}
\multicolumn{1}{c}{ Rating Urgensi } & Bobot \\
\hline $\begin{array}{l}\text { Tidak mampu untuk membuat } \\
\text { program dengan Bahasa apapun }\end{array}$ & 1 \\
$\begin{array}{l}\text { Mampu membuat program } \\
\text { sederhana dengan bimbingan }\end{array}$ & 2 \\
$\begin{array}{l}\text { Mampu membuat program } \\
\text { sederhana tanpa bimbingan } \\
\text { meskipun belum sempurna }\end{array}$ & 3 \\
$\begin{array}{l}\text { Mampu membuat program } \\
\text { sederhana tanpa bimbingan namun } \\
\text { belum menerapkan Object }\end{array}$ & 4 \\
$\begin{array}{l}\text { Oriented Programming } \\
\text { Mampu membuat program } \\
\text { sederhana tanpa bimbingan dan } \\
\text { sudah mampu menerapkan Object } \\
\text { Oriented Programming }\end{array}$ & 5 \\
\hline
\end{tabular}

Tabel 8. Bobot Referensi Teknologi Jaringan Berbasis Luas

\begin{tabular}{lc}
\hline \multicolumn{1}{c}{ Rating Urgensi } & Bobot \\
\hline $\begin{array}{l}\text { Tidak mampu setting dan } \\
\text { memasang mikrotik dan hotspot }\end{array}$ & 1 \\
$\begin{array}{l}\text { Hanya mampu setting hotspot } \\
\text { dengan bimbingan }\end{array}$ & 2 \\
$\begin{array}{l}\text { Hanya mampu memasang hotspot } \\
\text { Hanya mampu melakukan setting } \\
\text { hotspot }\end{array}$ & 3 \\
$\begin{array}{l}\text { Mampu setting dan memasang } \\
\text { hotspot }\end{array}$ & 5 \\
\hline
\end{tabular}

Tabel 9. Bobot Referensi Administrasi Infrastruktur Jaringan Rating Urgensi

Tidak mampu membuat desain Bobot jaringan dan settingnya

Butuh bimbingan untuk membuat 2

dan setting mikrotik

Hanya mampu membuat desain 3 jaringan

Hanya mampu setting mikrotik

Mampu membuat desain dan

4

setting mikrotik

\section{Analisa Kasus Dengan Metode SAW}

Analisa kasus dengan metode SAW dimulai dengan menentukan kriteria yang mempenaruhi kasus yang dihadapi. Pembahasan ini sudah dibahas pada Analisa kebutuhan input yang telah dijelaskan sebelumnya.

Langkah selanjutnya adalah menentukan rating kecocokan tiap alternatif dengan memberikan penilaian tiap kriteria yang dimiliki oleh alternatif. Data penilaian tiap kriteria pada alternatif disajikan pada uraian berikut:

Alternatif 1 adalah perusahaan Bina Widya Computer yang berusaha dalam bidang penjualan alat-alat computer. Alternatif 2 adalah 
STIKOM, kampus yang ditempati siswa dalam PKL. Alternatif 3 atau alternatif terakhir adalah AHASS bengkel resmi motor Honda.

Dari tiga lokasi yang menjadi tujuan Praktek Kerja Lapangan didapatkan penilaian kegiatan seperti ditampilkan dalam table hasil penilaian berikut:

Tabel 10. Penilaian kriteria dari alternatif yang

\begin{tabular}{ccccccccc}
\multicolumn{10}{c}{ N } & Nam & \multicolumn{8}{c}{ Kriteria } \\
\cline { 3 - 9 } O & a Alt & C & C & C & C & $\mathbf{C}$ & $\mathbf{C}$ & $\mathbf{C}$ \\
& & $\mathbf{1}$ & $\mathbf{2}$ & $\mathbf{3}$ & $\mathbf{4}$ & $\mathbf{5}$ & $\mathbf{6}$ & $\mathbf{7}$ \\
\hline 1 & Alt1 & 4 & 2 & 1 & 3 & 4 & 5 & 3 \\
2 & Alt2 & 3 & 4 & 5 & 5 & 4 & 4 & 3 \\
3 & Alt3 & 3 & 4 & 2 & 1 & 2 & 3 & 4 \\
\hline
\end{tabular}

Pemberi keputusan memberikan bobot referensi dari kriteria diatas sebagai berikut :

$\mathrm{W}=(5,4,4,3,4,3,5)$.

Pemberi keputusan memberikan bobot referensi dari kriteria diatas sebagai berikut :

$$
X=\left|\begin{array}{lllllll}
4 & 2 & 1 & 3 & 4 & 5 & 3 \\
3 & 4 & 5 & 5 & 4 & 4 & 3 \\
3 & 4 & 2 & 1 & 2 & 3 & 4
\end{array}\right|
$$

Dari data diatas diketahui bahwa nilai minimal dan maksimal masing-masing kriteria adalah sebagai berikut:

Tabel 11. Nilai Min dan Max kriteria

\begin{tabular}{cccccccc} 
Ket & C1 & C2 & C3 & C4 & C5 & C6 & C7 \\
\hline Min & 3 & 2 & 1 & 1 & 2 & 3 & 3 \\
Max & 4 & 4 & 5 & 5 & 4 & 5 & 4 \\
\hline
\end{tabular}

Hasil dari proses normalisasi dari matrik keputusan tersebut didapatkan data sebagai berikut:

Tabel 12. Hasil Normalisasi

\begin{tabular}{ccccccccc}
\hline $\mathrm{N}$ & Alt & \multicolumn{7}{c}{ Kriteria } \\
\cline { 3 - 9 } 0 & & C1 & C2 & C3 & C4 & C5 & C6 & C7 \\
\hline 1 & Alt & 1 & 0. & 0. & 0. & 1 & 1 & 0. \\
& 1 & & 5 & 2 & 6 & & & 8 \\
2 & Alt & 0.8 & 1 & 1 & 1 & 1 & 0. & 0. \\
& 2 & & & & & & 8 & 8 \\
3 & Alt & 0.8 & 1 & 0. & 0. & 0. & 0. & 1 \\
& 3 & & & 4 & 2 & 5 & 6 & \\
\hline
\end{tabular}

Selanjutkan kita tinggal melakukan perangkingan terhadap matrik ternormalisasi dengan cara mengalikan matrik ternormalisasi $(\mathrm{R})$ dengan bobot yang diberikan (W). sehingga hasil perkalian antara $\mathrm{R}$ dengan $\mathrm{W}$ adalah :
Tabel 13. Hasil Perangkingan

\begin{tabular}{ccccccccccc}
\hline No & Alt & \multicolumn{1}{c}{ Kriteria } & \multicolumn{1}{c}{ Total } & Rank \\
\cline { 3 - 8 } & & C1 & C2 & C3 & C4 & C5 & C6 & C7 & & \\
\hline 1 & Alt1 & 5 & 2 & 1 & 2 & 4 & 3 & 3.8 & 20.35 & 2 \\
2 & Alt2 & 3.8 & 4 & 4 & 3 & 4 & 2 & 3.8 & 24.9 & 1 \\
3 & Alt3 & 3.8 & 4 & 2 & 1 & 2 & 2 & 5 & 18.75 & 3 \\
\hline
\end{tabular}

\section{Hasil Dan Pembahasan}

1. Implementasi Sistem

Dari rancangan system yang dibuat Langkah keempat dalam penelitian ini adalah melakukan implementasi dari rancangan system yang dibuat. Implementasi system dilakukan dengan membuat aplikasi berbasis web dengan kerangka kerja Codeigniter.

\section{Halaman Antarmuka Login}

Ketika aplikasi pertama kali diakses maka akan masuk ke halaman login. Untuk dapat masuk ke system dibutuhkan username dan password serta level user, dalam hal ini level dibagi menjadi 3 kelompok yaitu prakerin, sekolah dan perusahaan.

Pengujian fitur akan dilakukan oleh user dengan level sekolah. Sehingga Ketika akan melakukan login user harus memilih level sebagai sekolah.

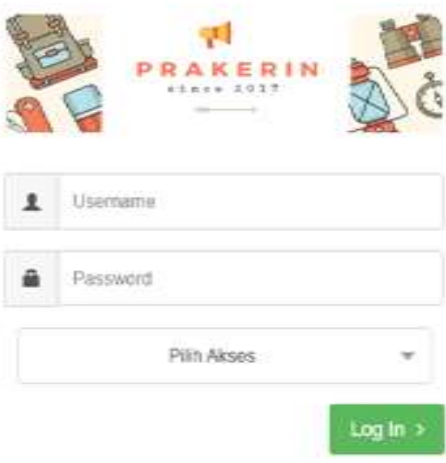

Gambar 3. Halaman Login

\section{Halaman Dashboard}

Halaman dashboard system berisi menu yang ada dalam system yang dibuat. Untuk masuk ke halaman SPK maka harus mengklik menu evaluasi perusahaan yang akan membawa pengunjung aplikasi kedalam aplikasi SPK yang telah dibuat.

Dari sinilah pengunjung dalam hal ini sekolah dapat menggunakan aplikasi SPK dengan menginputkan kriteria, alternatif dan penilaian terhadap setiap kriteria dan alternatif sehingga aplikasi akan otomatis memberikan hasil penilaian dengan hasil akhir rangking urutan perusahaan yang tepat untuk ditempati siswa melaksanakan kegiatan Praktek Kerja Lapangan. 


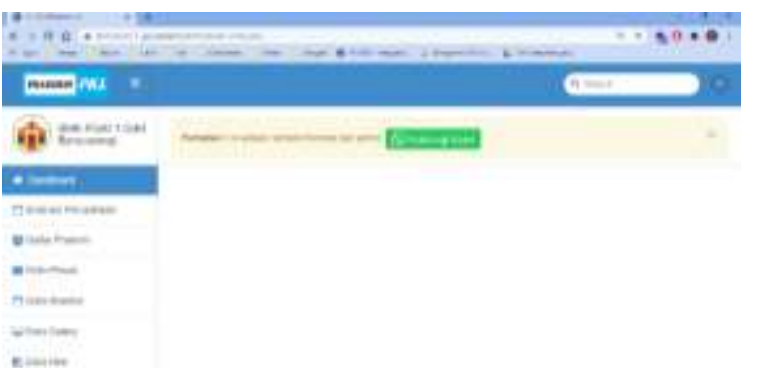

Gambar 4. Halaman Dashboard

4. Halaman Sub Menu Kriteria

Pada halaman ini sekolah dapat menambahkan kriteria yang diperlukan dalam menentukan tercapainya pencarian perusahaan yang tepat untuk siswa Praktek

Kerja Lapangan. Didalamnya terdapat tombol lihat, ubah kriteria, Lihat item kriteria dan hapus yang digunakan untuk managemen data kriteria

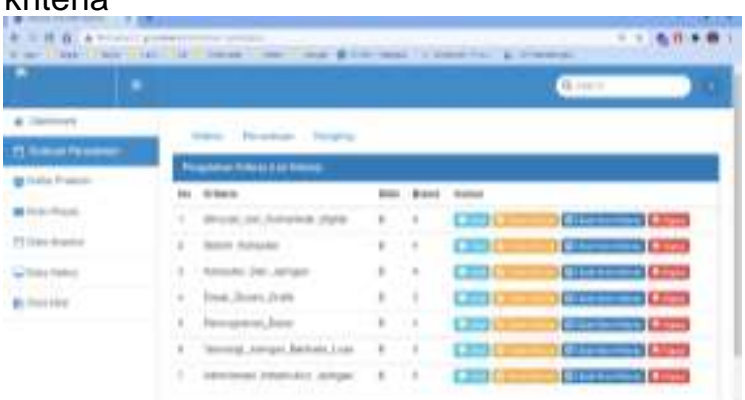

Gambar 5. Halaman menu Evaluasi Perusahaan Sub Menu Kriteria

5. Halaman sub menu Perusahaan

Pada halaman ini sekolah dapat menginputkan perusahaan mana saja yang akan dinilai kelayakanya untuk ditempati siswa praktek kerja lapangan. Didalamnya ada tombol tambah perusahaan, ubah dan hapus.

Perusahaan yang diinputkan adalah perusahaan yang sudah ditempati siswa praktek kerja lapangan di kegiatan yang sudah lalu. Sehingga penilaianya dapat dilakukan setelah selesainya kegiatan siswa.

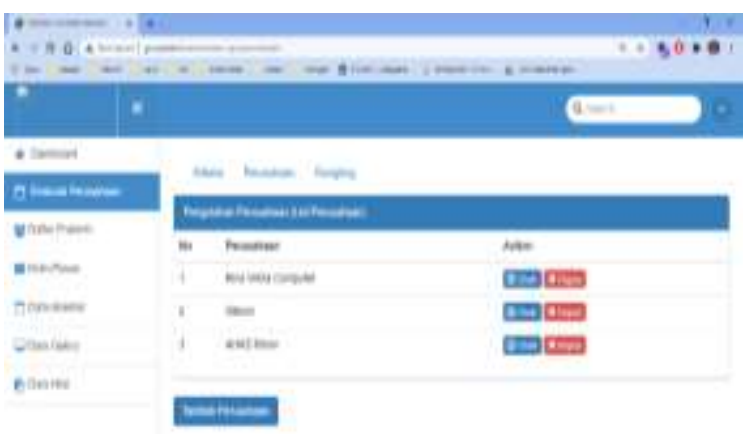

Gambar 6. Halaman menu Evaluasi Perusahaan Sub Menu Perusahaan
Dalam halaman ini sekolah akan diberikan hasil penilaian terhadap perusahaan sesuai dengan inputan pada halaman kriteria dan halaman perusahaan sebelumnya. Disini akan ditampilkan nilai awal, perhitungan sesuai dengan cost dan benefit, nilai minimal dan maksimal, bobot dan yang paling bawah ditampilkan hasil penghitungan sehingga ditampilkan rangking perusahaan yang dimasukkan.

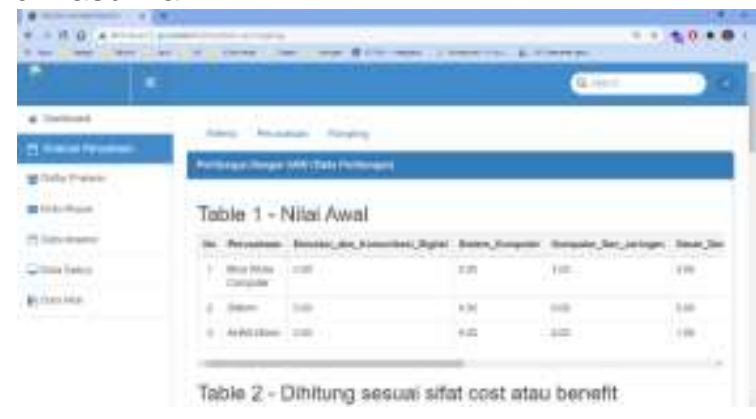

Gambar 7. Halaman menu Evaluasi Perusahaan Sub Menu Rangking

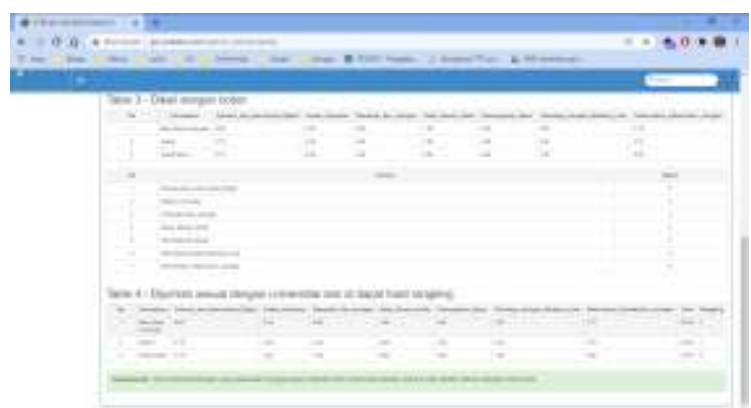

Gambar 8. Hasil Ranking dari perhitungan sistem

\section{Uji Coba}

Uji coba dilakukan untuk mengetahui apakah system yang dibuat sudah sesuai dengan harapan atau masih ada yang perlu ditambahkan dalam system agar memenuhi harapan penggunanya yaitu sekolah.

Untuk melakukan uji coba peneliti bekerja sama dengan stake holder dari SMK PGRI 1 Giri yaitu satu orang wakil kurikulum yang bertugas dalam penempatan siswa praktek kerja lapangan.

Uji coba dilakukan dengan metode blackbox untuk menguji fungsionalitas fitur yang dibuat(Tri Yani Akhirinaa , Dwi Yulistyantib, Ana Rusmardianac, 2018).

Proses pengujian dimulai dengan pengujian fungsionalitas login dan hasilnya seperti yang disajikan dalam table 14 .

\section{Halaman Sub Menu Rangking}


Table 14. Uji coba fungsionalitas halaman login

\begin{tabular}{|l|l|c|}
\hline \multicolumn{1}{|c|}{ Proses } & \multicolumn{1}{c|}{ Harapan } & Hasil \\
\hline $\begin{array}{l}\text { User } \\
\text { memasukkan } \\
\text { username, dan } \\
\text { password dan } \\
\text { level yang } \\
\text { sesuai }\end{array}$ & $\begin{array}{l}\text { Sistem } \\
\text { menampilkan } \\
\text { halaman sesuai } \\
\text { level pengguna }\end{array}$ & \\
\hline $\begin{array}{l}\text { User } \\
\text { memasukkan satu } \\
\text { salah sesuai } \\
\begin{array}{l}\text { username, dan } \\
\text { password dan } \\
\text { level salah }\end{array}\end{array}$ & $\begin{array}{l}\text { System } \\
\text { menampilkanan login }\end{array}$ & sesuai \\
\hline
\end{tabular}

Proses uji coba selanjutnya pihak sekolah akan menguji fungsionalitas input kriteria dan item penilaian kriteria. Hasil ujicoba ditampilkan pada table 15.

Selanjutnya sekolah melakukan uji coba fungsionalitas halaman input perusahaan yang akan dinilai kelayakanya. Hasil uji coba ditampilkan dalam table 16 . Ujicoba fungsionalitas kedua halaman ini menghasilkan kesesuaian dengan harapan user. Uji fungsionalitas halaman rangking dilakukan dengan mengecek halaman rangking dimana halaman ini akan menampilkan semua kriteria yang diinputkan beserta nilai awalnya, ditampilkan pula hasil normalisasi dan bobot yang diberikan kepada tiap kriteria.

Pada bagian bawah halaman akan ditampilkan hasil penghitungan dengan menampilkan hasil akhir penghitungan dan memberikan urutan dari yang tertinggi ke yang rendah. Seperti yang ditampilkan pada halaman bawah. Hasil uji coba ditampilkan pada table 17.

Semua ujicoba telah mendapatkan kesesuaian dengan harapan user seperti yang disajikan dalam table-tabel berikut:

Tabel 15. Uji coba fungsionalitas halaman input kriteria

\begin{tabular}{llc}
\hline \multicolumn{1}{c}{ Proses } & \multicolumn{1}{c}{ Harapan } & Hasil \\
\hline User & Sistem & Sesuai \\
memasukkan & menampilkan & \\
kriteria yang & kriteria yang & \\
berpengaruh & dimasukkan oleh & \\
terhadap & user & \\
penghitungan & & \\
User mengklik & System & Sesuai \\
tombol tambah & Menambahkan & \\
untuk & data dengan & \\
melakukan & menggunakan & \\
penambahan & tombol tambah & \\
kriteria yang & & \\
dibutuhkan & & \\
$\begin{array}{l}\text { User mengklik } \\
\text { tombol lihat }\end{array}$ & System menampilkan & \\
& &
\end{tabular}

untuk melihat detail kriteria detail kriteria yang ada dalam yang ada system

User mengklik System tombol ubah melakukan item kriteria perubahan data untuk sesuai keinginan mengubah user sesuai rule item penilaian yang diberikan dari kriteria User mengklik tombol hapus untuk System Sesuai menghapus diinginkan user kriteria yang ada

Tabel 16. Uji coba fungsionalitas halaman input perusahaan

\begin{tabular}{|c|c|c|}
\hline Proses & Harapan & Hasil \\
\hline $\begin{array}{l}\text { User } \\
\text { menambahkan } \\
\text { data } \\
\text { perusahaan } \\
\text { dengan } \\
\text { mengklik tombol } \\
\text { tambah } \\
\text { perusahaan }\end{array}$ & $\begin{array}{l}\text { System } \\
\text { menambahkan } \\
\text { data } \\
\text { perusahaan }\end{array}$ & Sesuai \\
\hline $\begin{array}{l}\text { User } \\
\text { memberikan } \\
\text { penilaian pada } \\
\text { perusahaan }\end{array}$ & $\begin{array}{l}\text { System } \\
\text { memberikan } \\
\text { penilaian } \\
\text { perusahaan }\end{array}$ & Sesuai \\
\hline $\begin{array}{l}\text { yang } \\
\text { ditambahkan } \\
\text { dengan memilih } \\
\text { cekbox yang } \\
\text { disediakan }\end{array}$ & $\begin{array}{l}\text { sesuai pilihan } \\
\text { user }\end{array}$ & \\
\hline $\begin{array}{l}\text { User melakukan } \\
\text { edit data } \\
\text { perusahaan dan } \\
\text { penilaian agar } \\
\text { sesuai dengan } \\
\text { rule penilaian } \\
\text { dengan cara klik } \\
\text { tombol ubah }\end{array}$ & $\begin{array}{l}\text { System } \\
\text { merubah data } \\
\text { perusahaan dan } \\
\text { penilaiannya } \\
\text { sesuai yang } \\
\text { diinputkan oleh } \\
\text { user }\end{array}$ & Sesuai \\
\hline $\begin{array}{l}\text { User } \\
\text { menghapus } \\
\text { data } \\
\text { perusahaan dan } \\
\text { penilaian }\end{array}$ & $\begin{array}{l}\text { System } \\
\text { menghapus } \\
\text { data } \\
\text { perusahaan dan } \\
\text { penilaianya }\end{array}$ & esuai \\
\hline $\begin{array}{l}\text { dengan klik } \\
\text { tombol hapus }\end{array}$ & $\begin{array}{l}\text { sesuai pilihan } \\
\text { user }\end{array}$ & \\
\hline
\end{tabular}


Tabel 17. Uji coba fungsionalitas halaman

\begin{tabular}{llc}
\multicolumn{1}{c}{ Ranking } & \\
\hline \multicolumn{1}{c}{ Proses } & \multicolumn{1}{c}{ Harapan } & Hasil \\
\hline User & System & Sesuai \\
halaman & menampilkan & \\
rangking & nilai awal pada & \\
& tiap kriteria & \\
& dan alternatif & \\
& System & Sesuai \\
& menampilkan & \\
& nilai hasil & \\
& normalisasi & \\
& dan bobot & \\
& pada tiap & \\
& kriteria & \\
& System Sesuai \\
& menampilkan & \\
& ranking tiap & \\
& alternatif & \\
& sesuai dengan & \\
& nilai akhir yang \\
& dimiliki tiap \\
& kriteria & \\
\end{tabular}

\section{Kesimpulan}

Pembuatan Sistem Pendukung Keputusan dengan mengimplementasikan metode Simple Additive Weighting (SAW) menghasilkan rangking perusahaan yang sesuai untuk digunakan oleh siswa. Terbukti dengan ditampilkanya perusahaan yang memiliki kualifikasi dan kelengkapan perangkat pendukung sebagai perusahaan paling direkomendasikan dalam system.

Dengan demikian pembuatan system pendukung keputusan berbasis web dengan mengimplementasikan metode simple additive weighting berhasil dibuat dan sesuai dengan harapan user pengguna system dalam hal ini sekolah.

Untuk pengembangan selanjutnya diharapkan system pendukung keputusan seperti ini dapat digunakan untuk membantu pihak sekolah dalam hal penempatan siswa, sehingga tujuan diadakanya kegiatan dapat tercapai sesuai tujuan yang diharapkan.

\section{Referensi}

Arianto, S. R., Siswanti, S., \& Saptomo, W. L. Y. (2020). Sistem Pendukung Keputusan Penerima Bantuan Pangan Non Tunai Dengan Metode Hybrid AHP- SAW. Jurnal Transformatika, $\quad 17(2), \quad 200$. https://doi.org/10.26623/transformatika.v1 $7 \mathrm{i} 2.1733$

Bambang Sumantri, R. B., \& Mahardika, F. (2020). Perancangan Basis Data Sistem
Informasi Penjualan Barang (Studi Kasus: Minimarket "ABC" Sidareja). Jurnal Teknologi Dan Bisnis, 2(1), 61-68. https://doi.org/10.37087/jtb.v2i1.16

Endang, D. (n.d.). Penerapan Metode Saw ( Simple Additive Weighting ) Untuk Menentukan Lokasi Kerja Praktik ( Studi Kasus: Jurusan Teknik Informatika Uin Sunan Gunung Djati Bandung ) Application Of The Saw (Simple Additive Weighting) Method For Determining Practice Work.

Ginting, J. V. B. (2020). Penerapan Sistem Pendukung Keputusan Dalam Menentukan e-Commerce Terbaik Dengan Menggunakan Metode SAW. Jurnal Media Informatika Budidarma, 4(1), 225. https://doi.org/10.30865/mib.v4i1.1986

Hafiz, A., Rakasiwi, G., Pratama, I. W., Komarudin, A., Suparapto, B., \& Ikhsan, K. (2020). Rancang Bangun Sistem Informasi Konseling Untuk Sekolah Menengah Kejuruan (Smk) Berbasis Website. Jurnal Informasi Dan Komputer, 8(1), 33-39. https://doi.org/10.35959/jik.v8i1.171

Khairullah, M. A., \& Mahdiana, D. (2019). Model Keputusan Maskapai Kargo Terbaik PT Budi Mandiri Cargo Metode Analitycal Hierarchy Process dan Simple Additive Weighting. Jurnal IDEALIS, 2(5), 204-209.

Mujiastuti, R., Komariyah, N., \& Hasbi, M. (2017). Sistem Penilaian Kinerja Karyawan Menggunakan Metode Simple Additive Weighting. Jurnal Sistem Informasi, Teknologi Informasi Dan Komputer, 9(2), 133-141.

Norman, N., Rosida, R., Putri, S., \& Nurahman, N. (2020). Penggunaan Sistem Pendukung Keputusan Seleksi Atlet Silat Sekotawaringin Timur Menggunakan Metode Simple Additive Weighting. Jurnal Sistem Komputer Dan Informatika (JSON), 1(2), 134. https://doi.org/10.30865/json.v1i2.1978

Sugihartono, T. (2018). Implementasi Sistem Pendukung Keputusan Penerima Bantuan Rumah Tidak Layak Huni Berbasis Web. Jurnal Sisfokom (Sistem Informasi Dan Komputer), $\quad 7(1), \quad 52$. https://doi.org/10.32736/sisfokom.v7i1.299

Sugiyono, N. (2012). Model Peta Digital Rawan Sambaran Petir Dengan Menggunakan Metode Saw ( Simple Additive Weighting ): Studi Kasus Propinsi Lampung. Jurnal Telematika MKOM, ISSN: 2085-725X, 4(1), 90-96.

Sumitro, A. H., \& Taufiq, M. (2019). Manajemen Praktek Kerja Lapangan Menggunakan Metode RAD dan Pengujian SUS pada Instansi SMK dan CV. RESEARCH: Computer, Information System \& 
Technology Management, 2(2), 51. https://doi.org/10.25273/research.v2i02.51 72

Susanto, G. A., Darmanto, E., \& Arifin, M. A. (2016). Sistem Monitoring Praktek Kerja Lapangan (Pkl) Pada Smk Assa'ldiyyah. Prosiding SNATIF, 255-260. https://doi.org/10.2298/PAN0903301G

Taufiq, M., Affandy, A., \& Marjuni, A. (2017). Fuzzy Goal Programming Untuk Pembobotan Analytical Hierarchy Process Pada Penentuan Penerima Bantuan Siswa Miskin. Cyberku Journal, 13(2), 5-5. http://research.pps.dinus.ac.id/index.php/ Cyberku/article/view/31

Tri Yani Akhirinaa, Dwi Yulistyantib, Ana Rusmardianac, U. P. (2018). Pengujian Sistem Pendukung Keputusan Penjurusan SMA di Banten menggunakan Metode
Black Box. Jurnal RESTI (Rekayasa Sistem Dan Teknologi Informasi), 2(3), 800-806.

Winarso, D., Nurita, F., \& Syahril, S. (2018). Penerapan Metode Weigth Product Untuk Rekomendasi Penempatan Praktek Kerja Industri (Study Kasus: SMK Muhammadiyah 01 Pekanbaru). Jurnal RESTI (Rekayasa Sistem Dan Teknologi Informasi), 2(2), 566-571. https://doi.org/10.29207/resti.v2i2.467 